\title{
Comparison of three aerosol chemical characterization techniques utilizing PTR-ToF-MS: a study on freshly formed and aged biogenic SOA
}

Georgios I. Gkatzelis et al.

Correspondence to: Ralf Tillmann (r.tillmann@fz-juelich.de)

The copyright of individual parts of the supplement might differ from the CC BY 4.0 License. 
Table S 1: Major detected ion signals and their possible compound attribution that overlap with compound identifications from previous publications. These compounds correspond to the orange circle markers shown in Figure 7. The detected ion column indicates whether the PTR based techniques were able to detect the parent ion $[\mathrm{M}+\mathrm{H}]^{+}$or the parent ion after water loss $\left[\mathrm{M}+\mathrm{H}-\mathrm{H}_{2} \mathrm{O}\right]^{+}$due to fragmentation including the detected exact protonated $\mathrm{m} / \mathrm{z}$.

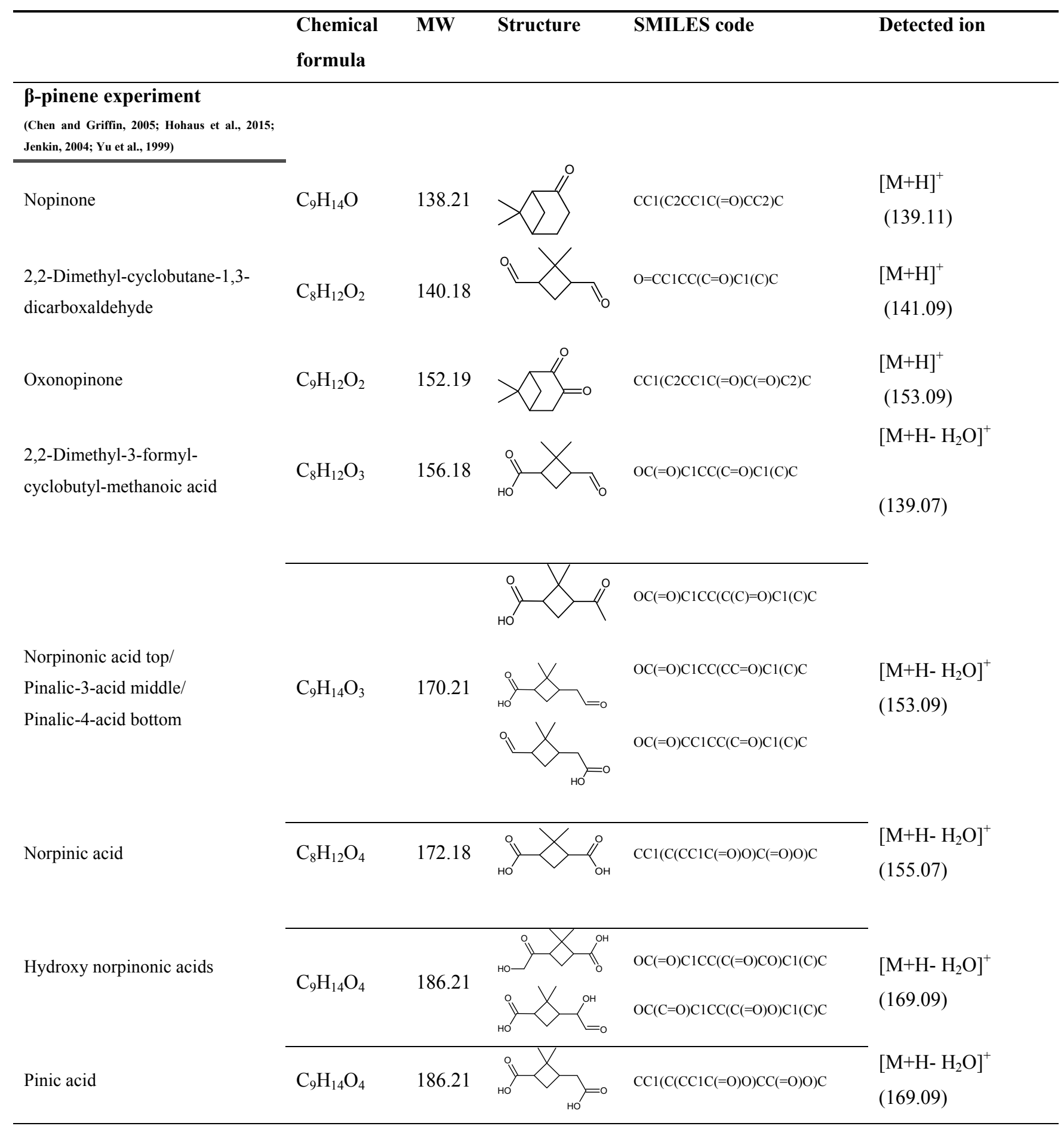




\begin{tabular}{|c|c|c|c|c|}
\hline $\begin{array}{l}\text { Limonene experiment } \\
\text { (Chen and Griffin, 2005; Jaoui et al, 2006; } \\
\text { Kundu et al, 2012; Leungsakul et al., 2005a; } \\
\text { Leungsakul et al,, 2005b) }\end{array}$ & & & & \\
\hline 3-Oxobutanal & $\mathrm{C}_{4} \mathrm{H}_{6} \mathrm{O}_{2}$ & 86.09 & $\mathrm{CC}(=0) \mathrm{CC}=\mathrm{O}$ & $\begin{array}{l}{[\mathrm{M}+\mathrm{H}]^{+}} \\
\text {protonated molecule } \\
(87.04)\end{array}$ \\
\hline Levulinic acid & $\mathrm{C}_{5} \mathrm{H}_{8} \mathrm{O}_{3}$ & 116.12 & $\mathrm{CC}(=\mathrm{O}) \mathrm{CCC}(=\mathrm{O}) \mathrm{O}$ & $\begin{array}{l}{\left[\mathrm{M}+\mathrm{H}-\mathrm{H}_{2} \mathrm{O}\right]^{+}} \\
(99.04)\end{array}$ \\
\hline Pentanedioic acid & $\mathrm{C}_{5} \mathrm{H}_{8} \mathrm{O}_{4}$ & 132.11 & $\mathrm{OC}(=\mathrm{O}) \operatorname{CCCCC}(=0) \mathrm{O}$ & $\begin{array}{l}{\left[\mathrm{M}+\mathrm{H}-\mathrm{H}_{2} \mathrm{O}\right]^{+}} \\
(115.04)\end{array}$ \\
\hline 3,6-Oxoheptanoic acid & $\mathrm{C}_{7} \mathrm{H}_{10} \mathrm{O}_{4}$ & 158.15 & $\mathrm{O}=\mathrm{C}(\mathrm{CCC}(\mathrm{C})=\mathrm{O}) \mathrm{CC}(=\mathrm{O}) \mathrm{O}$ & $\begin{array}{l}{\left[\mathrm{M}+\mathrm{H}-\mathrm{H}_{2} \mathrm{O}\right]^{+}} \\
(141.05)\end{array}$ \\
\hline Limonalic acid & $\mathrm{C}_{9} \mathrm{H}_{14} \mathrm{O}_{3}$ & 170.21 & $\mathrm{O}=\mathrm{CCC}(\mathrm{CCC}(=\mathrm{O}) \mathrm{O}) \mathrm{C}(=\mathrm{C}) \mathrm{C}$ & $\begin{array}{l}{\left[\mathrm{M}+\mathrm{H}-\mathrm{H}_{2} \mathrm{O}\right]^{+}} \\
(153.09)\end{array}$ \\
\hline Norlimononic acid & $\mathrm{C}_{9} \mathrm{H}_{14} \mathrm{O}_{3}$ & 170.21 & $\mathrm{O}=\mathrm{C}(\mathrm{C}) \mathrm{CCC}(\mathrm{C}(=\mathrm{C}) \mathrm{C}) \mathrm{C}(=\mathrm{O}) \mathrm{O}$ & $\begin{array}{l}{\left[\mathrm{M}+\mathrm{H}-\mathrm{H}_{2} \mathrm{O}\right]^{+}} \\
(153.09)\end{array}$ \\
\hline Ketolimononaldehyde & $\mathrm{C}_{9} \mathrm{H}_{14} \mathrm{O}_{3}$ & 170.21 & $\mathrm{CC}(=\mathrm{O}) \mathrm{C}(\mathrm{CC}=\mathrm{O}) \mathrm{CCC}(=\mathrm{O}) \mathrm{C}$ & $\begin{array}{l}{\left[\mathrm{M}+\mathrm{H}-\mathrm{H}_{2} \mathrm{O}\right]^{+}} \\
(153.09)\end{array}$ \\
\hline Norlimonic acid & $\mathrm{C}_{8} \mathrm{H}_{12} \mathrm{O}_{4}$ & 172.18 & $\mathrm{OC}(=\mathrm{O}) \mathrm{CCC}(\mathrm{C}(=\mathrm{C}) \mathrm{C}) \mathrm{C}(=\mathrm{O}) \mathrm{O}$ & $\begin{array}{l}{\left[\mathrm{M}+\mathrm{H}-\mathrm{H}_{2} \mathrm{O}\right]^{+}} \\
(155.07)\end{array}$ \\
\hline Limononic acid & $\mathrm{C}_{10} \mathrm{H}_{16} \mathrm{O}_{3}$ & 184.23 & $\mathrm{O}=\mathrm{C}(\mathrm{C}) \mathrm{CCC}(\mathrm{CC}(=\mathrm{O}) \mathrm{O}) \mathrm{C}(=\mathrm{C}) \mathrm{C}$ & $\begin{array}{l}{\left[\mathrm{M}+\mathrm{H}-\mathrm{H}_{2} \mathrm{O}\right]^{+}} \\
(167.11)\end{array}$ \\
\hline $\begin{array}{l}\text { 4-Isopropenyl-1-methyl-1,5- } \\
\text { hydroxy-2-oxocyclohexane }\end{array}$ & $\mathrm{C}_{10} \mathrm{H}_{16} \mathrm{O}_{3}$ & 184.23 & $\mathrm{CC}(=\mathrm{C}) \mathrm{ClCC}(=0) \mathrm{C}(\mathrm{C})(\mathrm{O}) \mathrm{CC} 1 \mathrm{O}$ & $\begin{array}{l}{\left[\mathrm{M}+\mathrm{H}-\mathrm{H}_{2} \mathrm{O}\right]^{+}} \\
(167.11)\end{array}$ \\
\hline 7-Hydroxylimononaldehyde & $\mathrm{C}_{10} \mathrm{H}_{16} \mathrm{O}_{3}$ & 184.23 & $\mathrm{O}=\mathrm{C}(\mathrm{CCC}(\mathrm{CC}=\mathrm{O}) \mathrm{C}(=\mathrm{C}) \mathrm{C}) \mathrm{CO}$ & $\begin{array}{l}{\left[\mathrm{M}+\mathrm{H}-\mathrm{H}_{2} \mathrm{O}\right]^{+}} \\
(167.11)\end{array}$ \\
\hline Ketolimononic acid & $\mathrm{C}_{9} \mathrm{H}_{14} \mathrm{O}_{4}$ & 186.21 & $\mathrm{O}=\mathrm{C}(\mathrm{C}) \operatorname{CCC}(\mathrm{CC}(=\mathrm{O}) \mathrm{O}) \mathrm{C}(\mathrm{C})=\mathrm{O}$ & $\begin{array}{l}{\left[\mathrm{M}+\mathrm{H}-\mathrm{H}_{2} \mathrm{O}\right]^{+}} \\
(169.09)\end{array}$ \\
\hline
\end{tabular}




\begin{tabular}{|c|c|c|c|c|}
\hline Limonic acid & $\mathrm{C}_{9} \mathrm{H}_{14} \mathrm{O}_{4}$ & 186.21 & $\mathrm{OC}(=\mathrm{O}) \mathrm{CCC}(\mathrm{CC}(=\mathrm{O}) \mathrm{O}) \mathrm{C}(=\mathrm{C}) \mathrm{C}$ & $\begin{array}{l}{\left[\mathrm{M}+\mathrm{H}-\mathrm{H}_{2} \mathrm{O}\right]^{+}} \\
(169.09)\end{array}$ \\
\hline Ketolimonic acid & $\mathrm{C}_{8} \mathrm{H}_{12} \mathrm{O}_{5}$ & 188.18 & $\mathrm{OC}(=\mathrm{O}) \mathrm{CCC}(\mathrm{CC}(=\mathrm{O}) \mathrm{O}) \mathrm{C}(\mathrm{C})=\mathrm{O}$ & $\begin{array}{l}{\left[\mathrm{M}+\mathrm{H}-\mathrm{H}_{2} \mathrm{O}\right]^{+}} \\
(171.06)\end{array}$ \\
\hline 5-Hydroxylimononic acid & $\mathrm{C}_{10} \mathrm{H}_{16} \mathrm{O}_{4}$ & 200.23 & $\mathrm{O}=\mathrm{C}(\mathrm{C}) \mathrm{C}(\mathrm{O}) \mathrm{CC}(\mathrm{CC}(\mathrm{O})=\mathrm{O}) \mathrm{C}(=\mathrm{C}) \mathrm{C}$ & $\begin{array}{l}{\left[\mathrm{M}+\mathrm{H}-\mathrm{H}_{2} \mathrm{O}\right]^{+}} \\
(183.10)\end{array}$ \\
\hline 7-Hydroxylimononic acid & $\mathrm{C}_{10} \mathrm{H}_{16} \mathrm{O}_{4}$ & 200.23 & $\mathrm{O}=\mathrm{C}(\mathrm{CCC}(\mathrm{CC}(=\mathrm{O}) \mathrm{O}) \mathrm{C}(=\mathrm{C}) \mathrm{C}) \mathrm{CO}$ & $\begin{array}{l}{\left[\mathrm{M}+\mathrm{H}-\mathrm{H}_{2} \mathrm{O}\right]^{+}} \\
(183.10)\end{array}$ \\
\hline
\end{tabular}

\section{Trees experiment}

( $\alpha$-pinene $/ \Delta^{3}$-carene)

(Chen and Griffin, 2005; Praplan et al., 2014;

Yu et al., 1999)

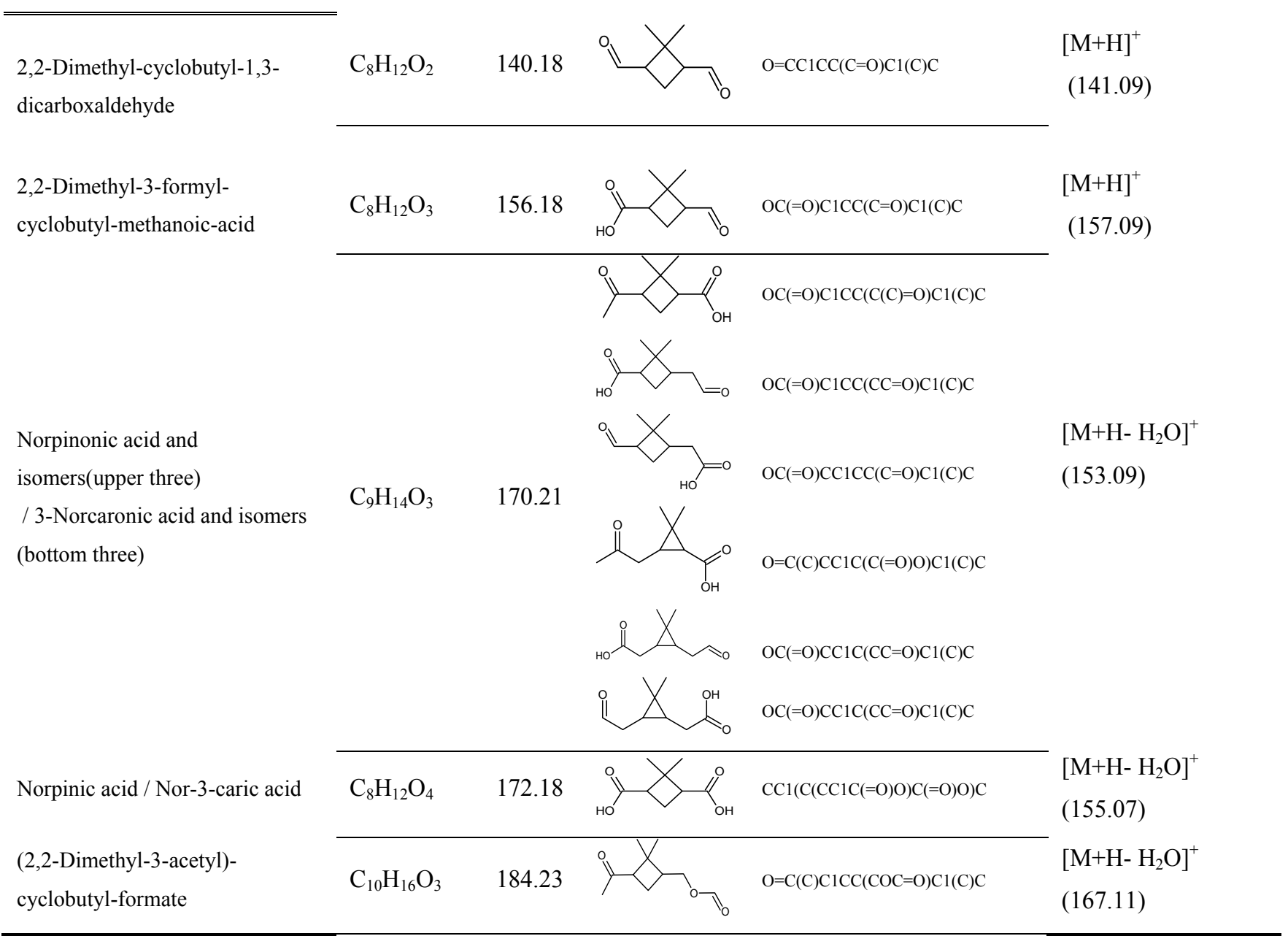




\begin{tabular}{llll}
\hline Pinonic acid / 3-caronic acid & $\mathrm{C}_{10} \mathrm{H}_{16} \mathrm{O}_{3}$ & 184.23 \\
Hydroxy pinonaldehydes \\
(upper two) \\
$\begin{array}{l}\text { / Hydroxy 3-caronic acid } \\
\text { (bottom) }\end{array}$
\end{tabular}



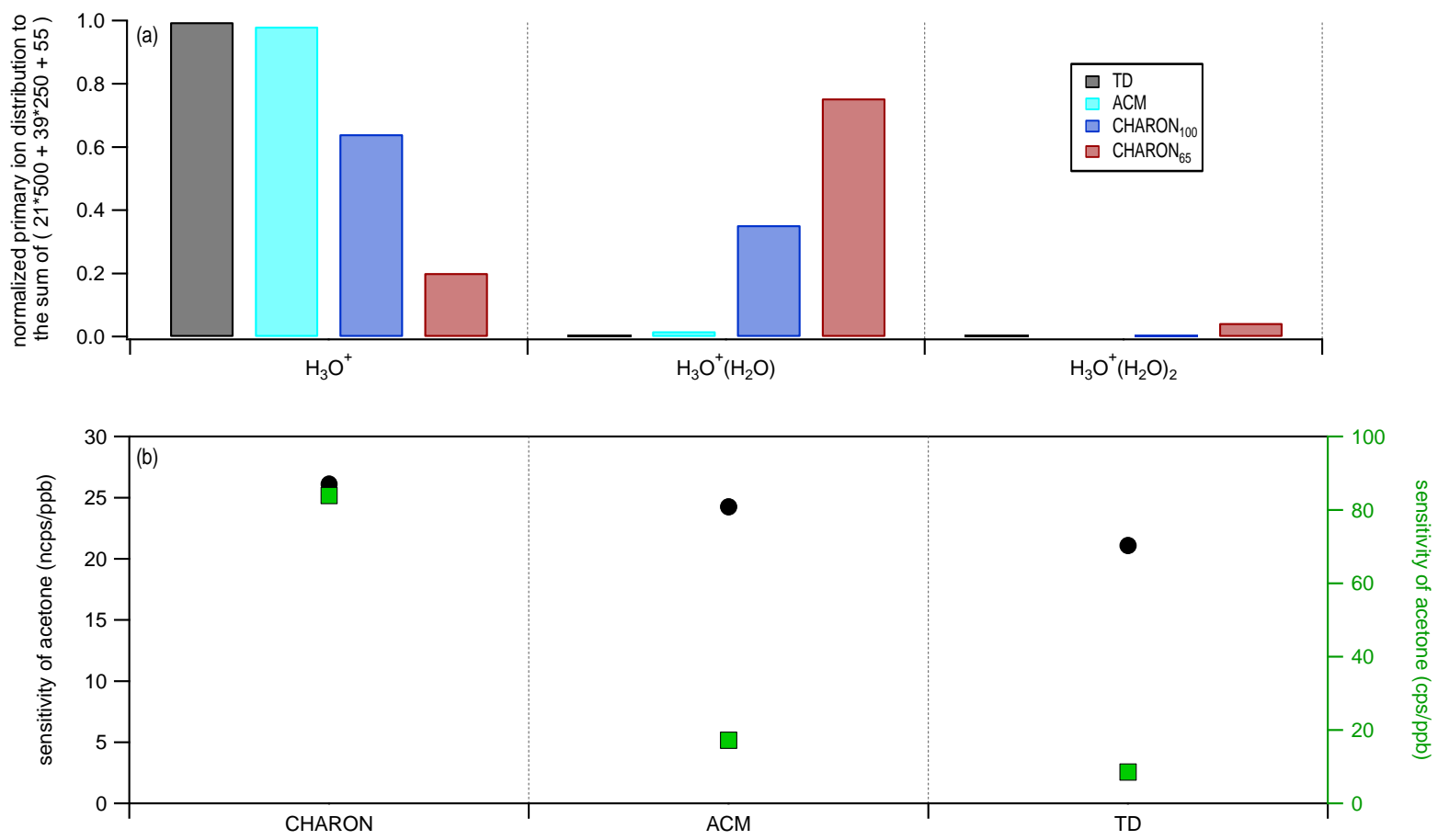

Figure S 1: (a) The normalized primary ion distribution as observed for the different PTR-based techniques operated at different $\mathbf{E} / \mathrm{N}$ conditions and (b) the sensitivity of acetone both in counts per second (cps) per ppbV and normalized cps (ncps) per ppb for each instrument. 


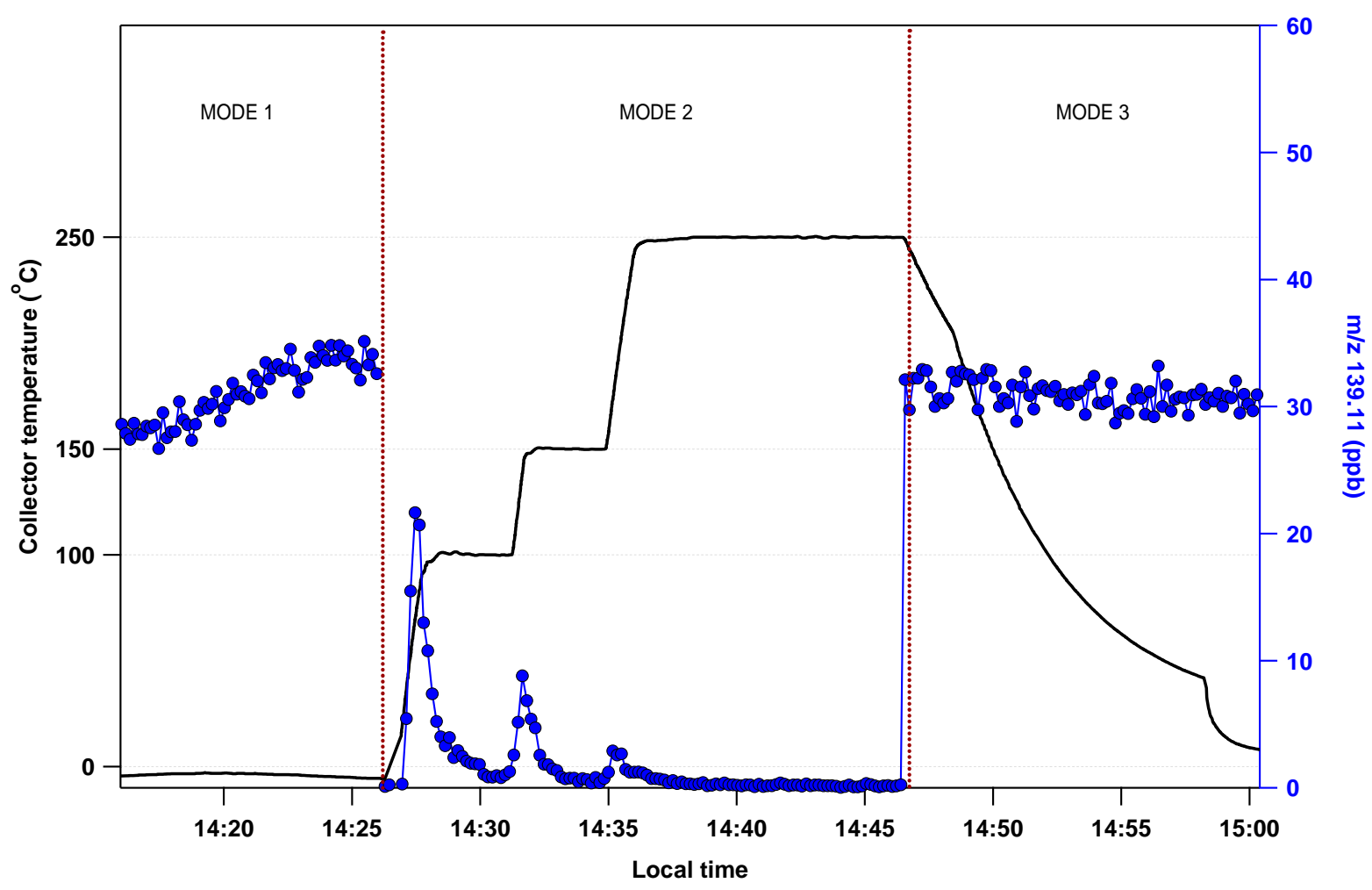

Figure S 2: Different modes of operation of the ACM-PTR-ToF-MS during the $\beta$-pinene ozonolysis experiment. Left axis correspond to the temperature of the collector and right axis to the ppb's measured for $\mathrm{m} / \mathrm{z} 139.11$ (corresponding to nopinone) with time. MODE 1 indicates the particulate phase collection on the cooled ACM collector and the parallel gas phase measurements of the PTR-ToF-MS. MODE 2 is the desorption of particulate phase compounds from the collector at the different temperature steps and MODE 3 corresponds to gas phase measurements and the intermediate step of cooling down the collector in order to initiate the next collection. 

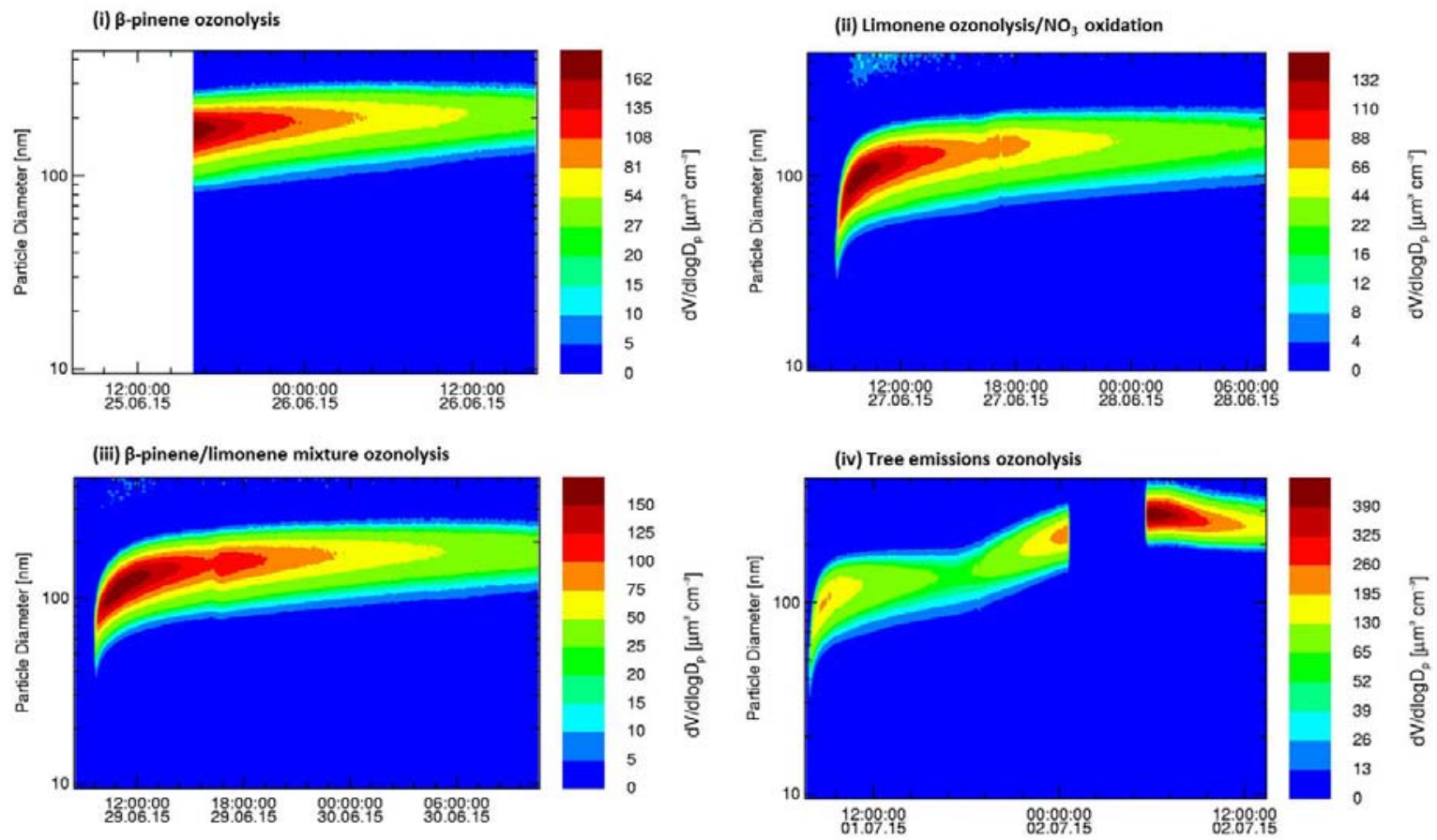

Figure S 3: The volume size distribution measured from an SMPS during the (i) $\beta$-pinene, (ii) limonene, (iii) $\beta$ pinene/limonene mixture and (iv) tree emissions oxidation experiments. 

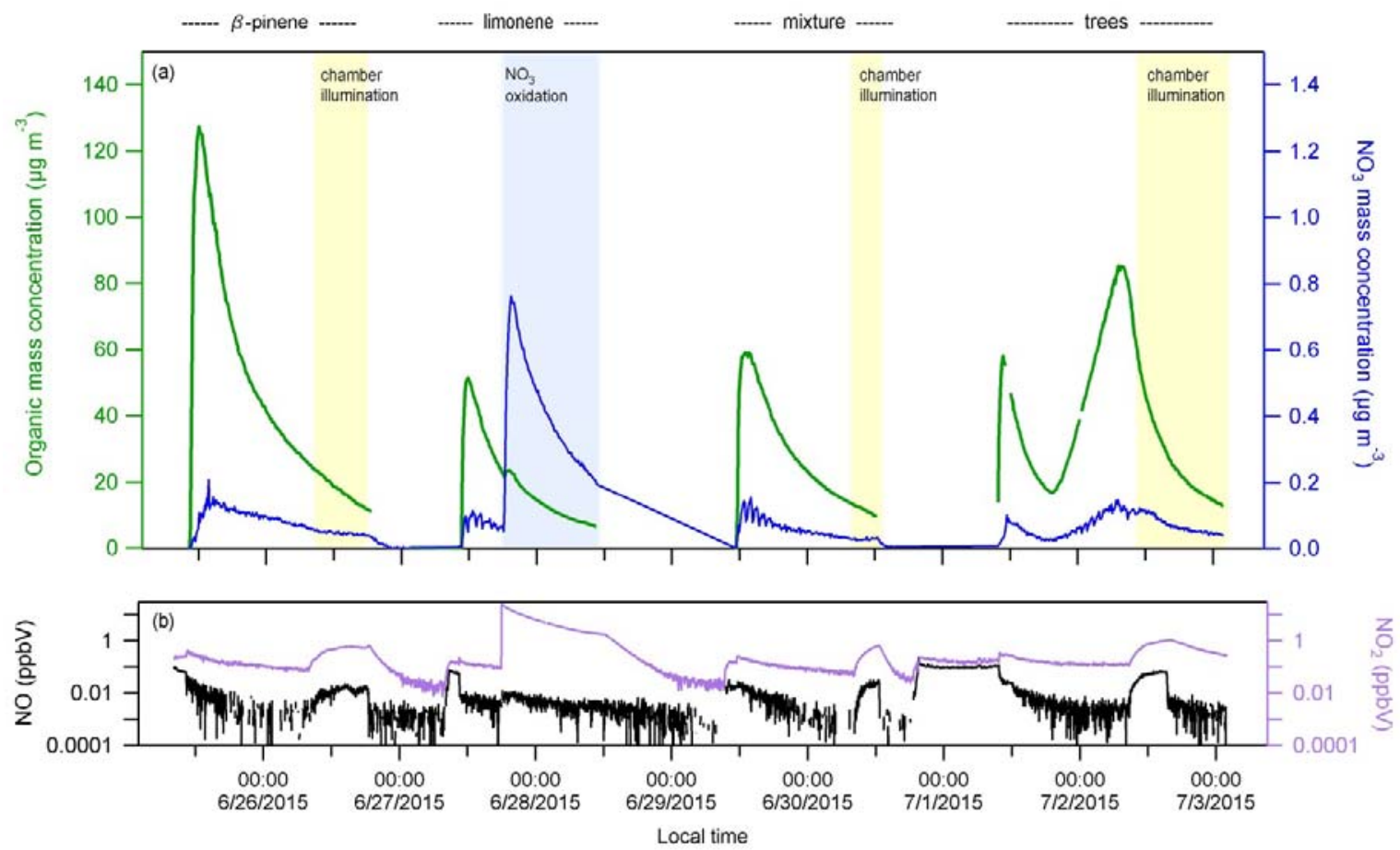

Figure S 4: The time series of (a) the particulate organic mass concentration (left axis) and nitrate mass concentration (right axis) in $\mu \mathrm{g} \mathrm{m}^{-3}$ and (b) the gas-phase $\mathrm{NO}$ (left axis) and $\mathrm{NO}_{2}$ (right axis) mixing ratios in ppbV throughout the campaign. Information on the type of precursor experiment performed is provided above the graph together with indications for periods of the chamber illumination (yellow background color) and $\mathrm{NO}_{3}$ oxidation (blue background color). The maximum organic nitrate fraction can be estimated from the measurement of the total nitrate derived by AMS. Adding an organic backbone to the nitrate with a maximum molecular weight of $180 \mathrm{~g} \mathrm{~mol}^{-1}$ results in a total organic nitrate concentration of $\mathrm{M}\left(\mathrm{NO}_{3}{ }^{-}+\mathrm{Org}\right) / \mathrm{M}\left(\mathrm{NO}_{3}^{-}\right)^{*} \mathrm{C}\left(\mathrm{NO}_{3}{ }^{-}\right)_{\max }=(62+180) /(62) * 0.8=3.1 \mu \mathrm{g} \mathrm{m}^{-3}$ which corresponds to a maximum of $10 \%$ for the limonene $\mathrm{NO}_{3}$ oxidation. 


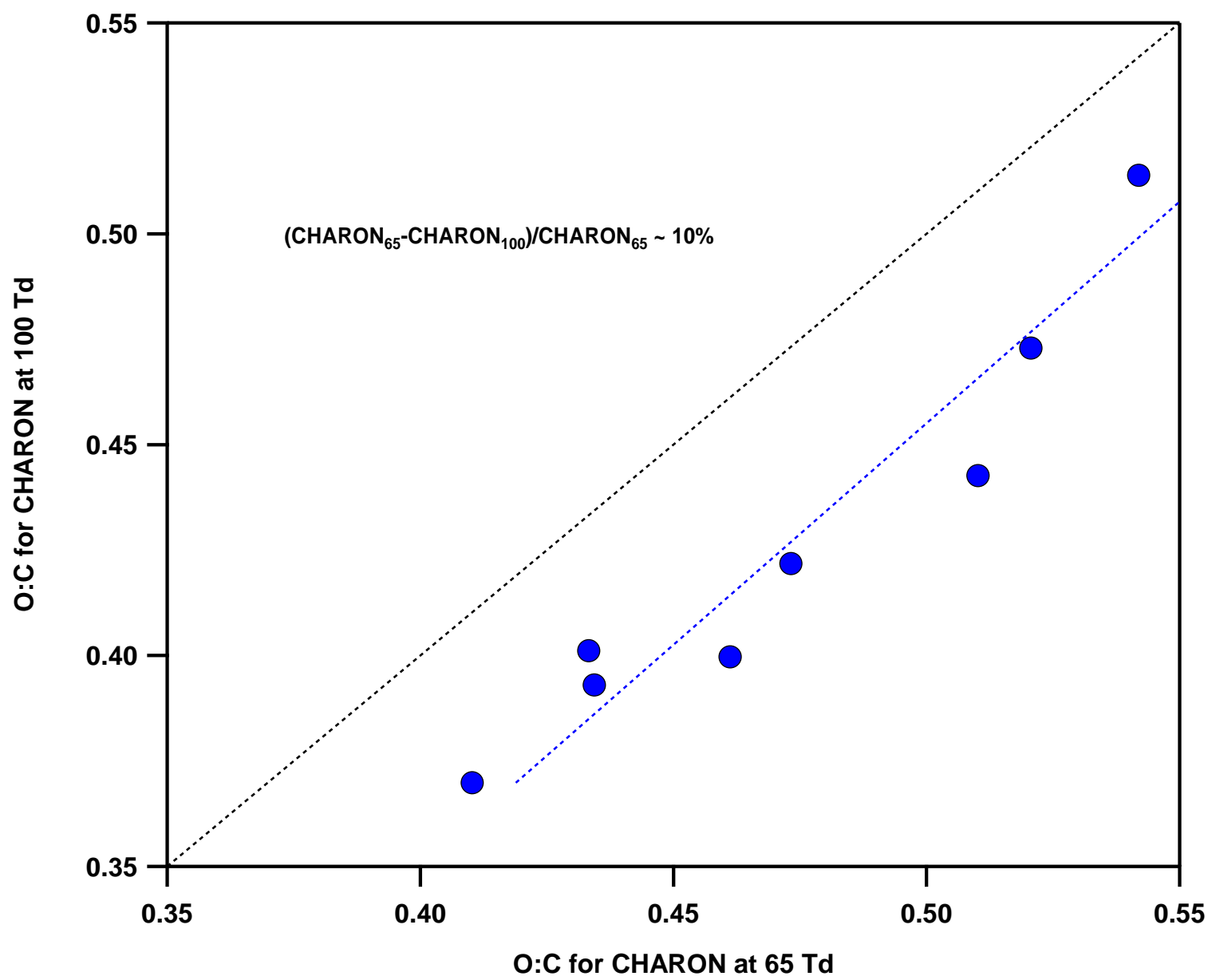

Figure $S$ 5: Comparison of the tree emissions oxygen to carbon ratio for the different $E / N$ conditions the CHARON was operated (x-axis for E/N $65 \mathrm{Td}$ and $\mathrm{y}$-axis for $\mathrm{E} / \mathrm{N} 100 \mathrm{Td}$ ). The black dash line indicates the 1:1 line and the blue dash line is the linear fit applied to the data. The upper right equation provides the average \% difference between the two data sets. 


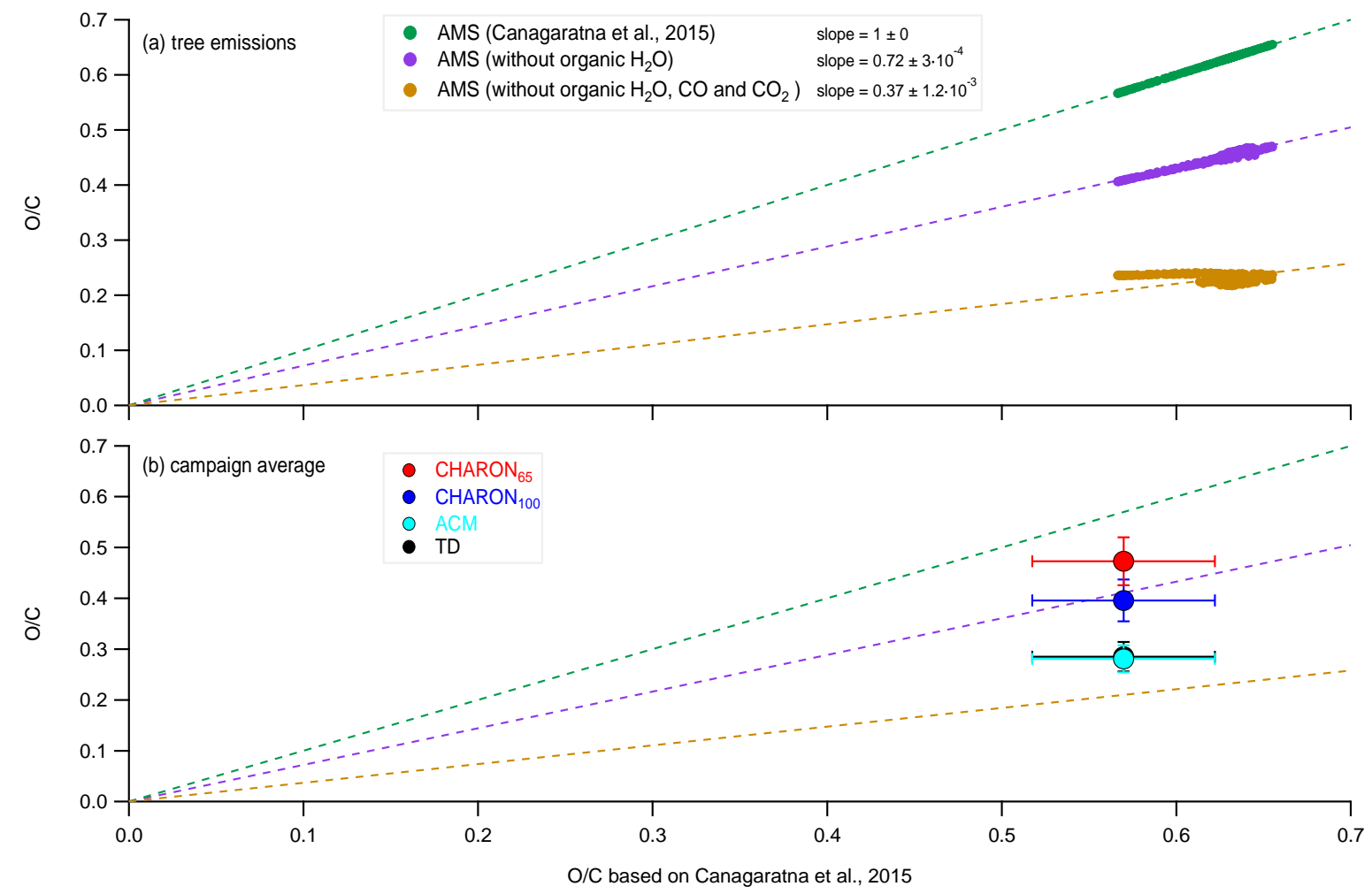

Figure S 6: The AMS O:C based on Canagaratna et al. (2015)(x-axis) compared to (a) the AMS O:C during the tree emissions ozonolysis experiment, when excluding surface fragmentation peaks $\left(\mathrm{H}_{2} \mathrm{O}, \mathrm{CO}\right.$ and $\left.\mathrm{CO}_{2}\right)$ and (b) the different aerosol chemical characterization techniques average $\mathrm{O}: \mathrm{C}$ throughout the campaign. $\mathrm{CHARON}_{65}$ data are averaged only for the tree emissions experiment. Error bars indicate the \pm 1 standard deviation of the average both for the AMS and the different aerosol chemical characterization techniques. Dash lines correspond to the linear fit of the AMS case studies (green: AMS based on Canagaratna et al., 2015, purple: AS without organic $\mathrm{H}_{2} \mathrm{O}$ peak and brown: AMS without organic $\mathrm{H}_{2} \mathrm{O}, \mathrm{CO}$ and $\left.\mathrm{CO}_{2}\right)$. 


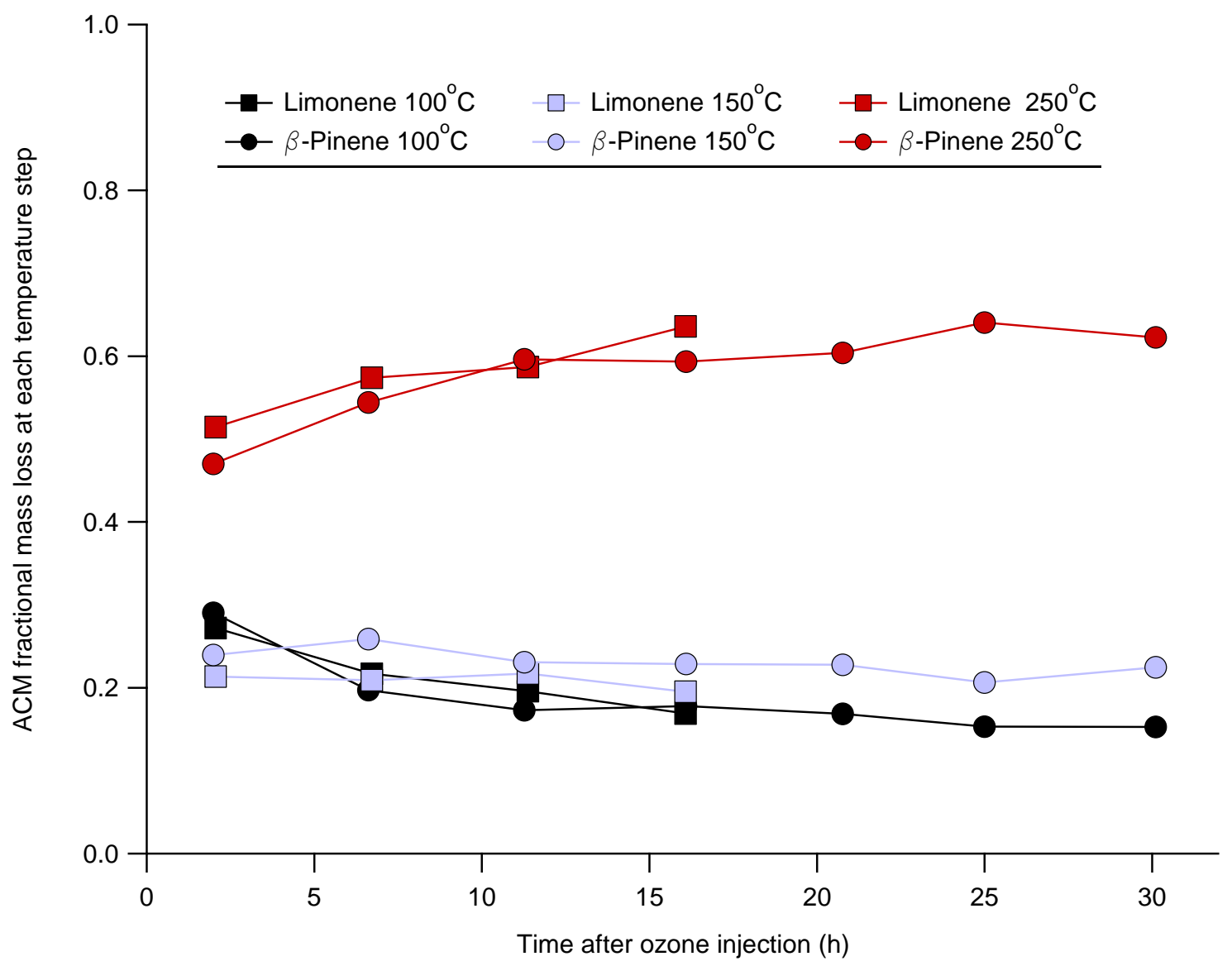

Figure S 7: Temperature contribution of the ACM during the $\beta$-pinene (circle markers) and limonene (square markers) experiment versus the time after ozone injection. Different colors correspond to different temperatures. 

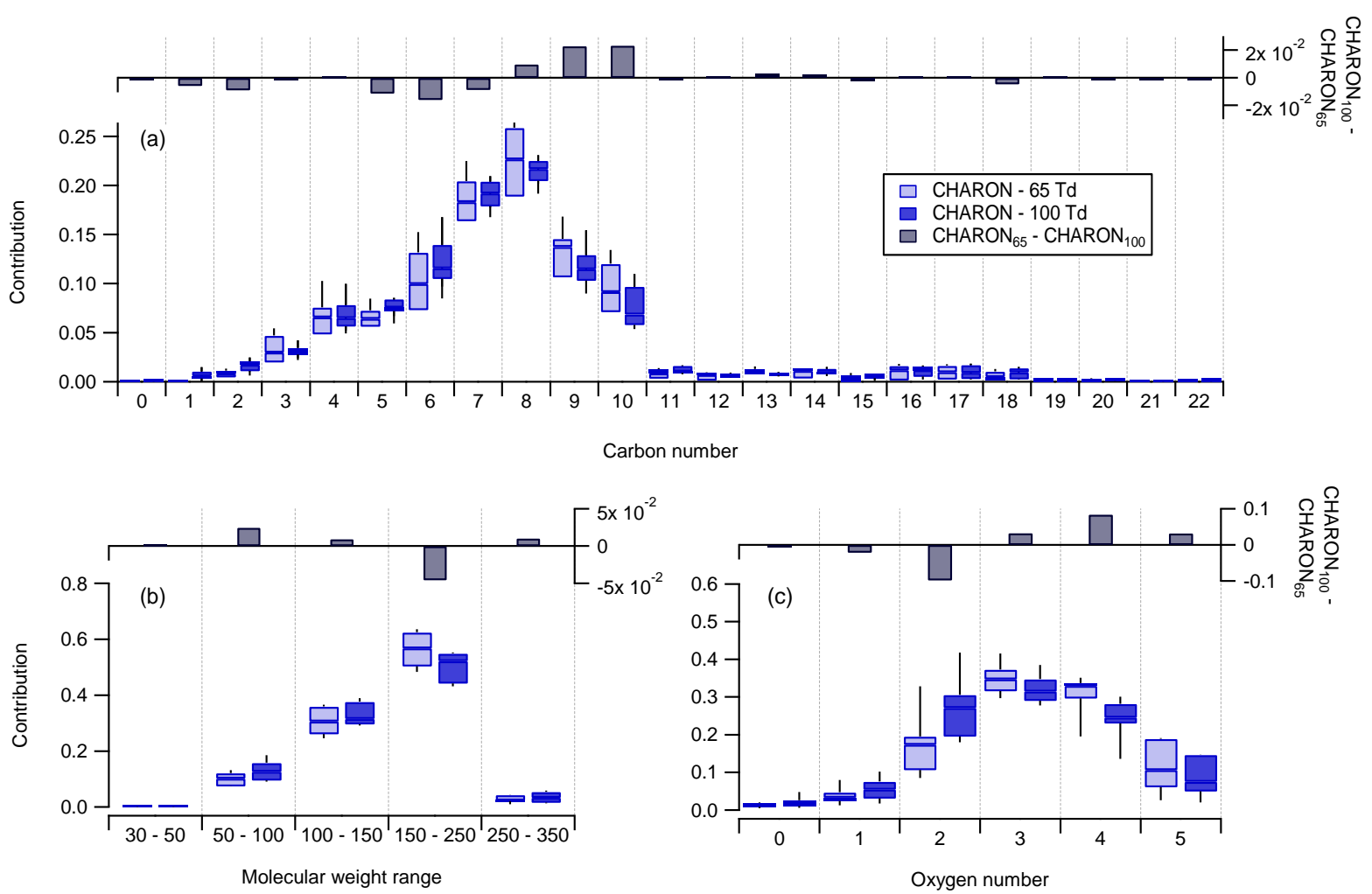

Figure S 8: Box-and-whisker plots showing the relative OA mass concentration distribution dependent on (a) molecular carbon number, (b) molecular weight and (c) molecular oxygen number for the tree emissions experiment and CHARON operated at two different $\mathrm{E} / \mathrm{N}$ conditions indicated with different colours $\left(\mathrm{CHARON}_{100}\right.$ dark blue, $\mathrm{CHARON}_{65}$ ciel). Each box-and-whisker corresponds to the median, $25^{\text {th }}$ and $75^{\text {th }}$ percentile levels of all data for the tree emissions experiment. Upper graphs indicate the difference between the CHARON operated at 65 Td to the $100 \mathrm{Td}$. 


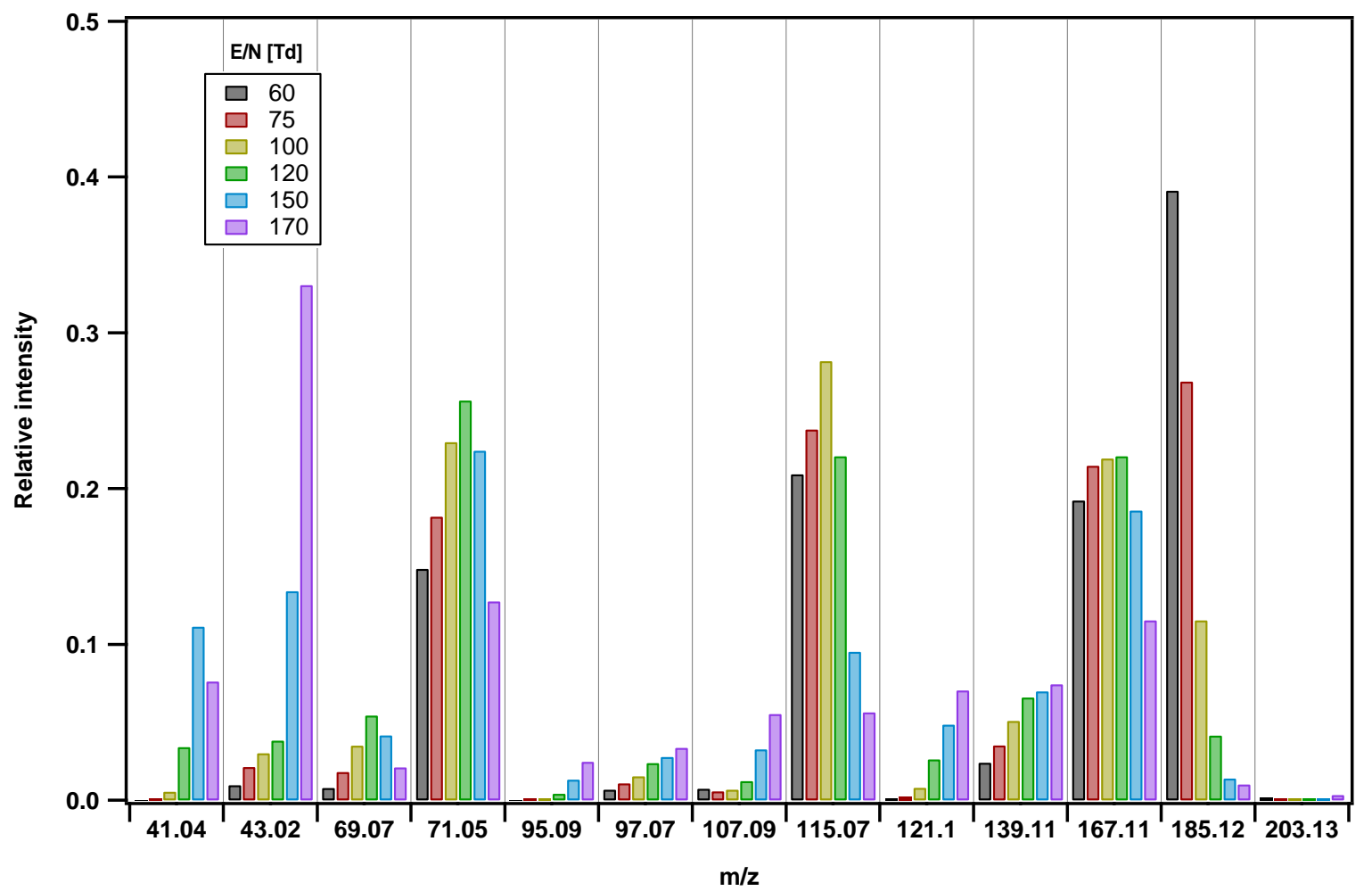

Figure S 9: Lab experiments to measure pinonic acid at different $E / N$ conditions. Relative intensity of each $\mathrm{m} / \mathrm{z}$ (transmission corrected normalized counts per second fraction) for the different $\mathrm{E} / \mathrm{N}$ conditions indicated by the bar colour. 


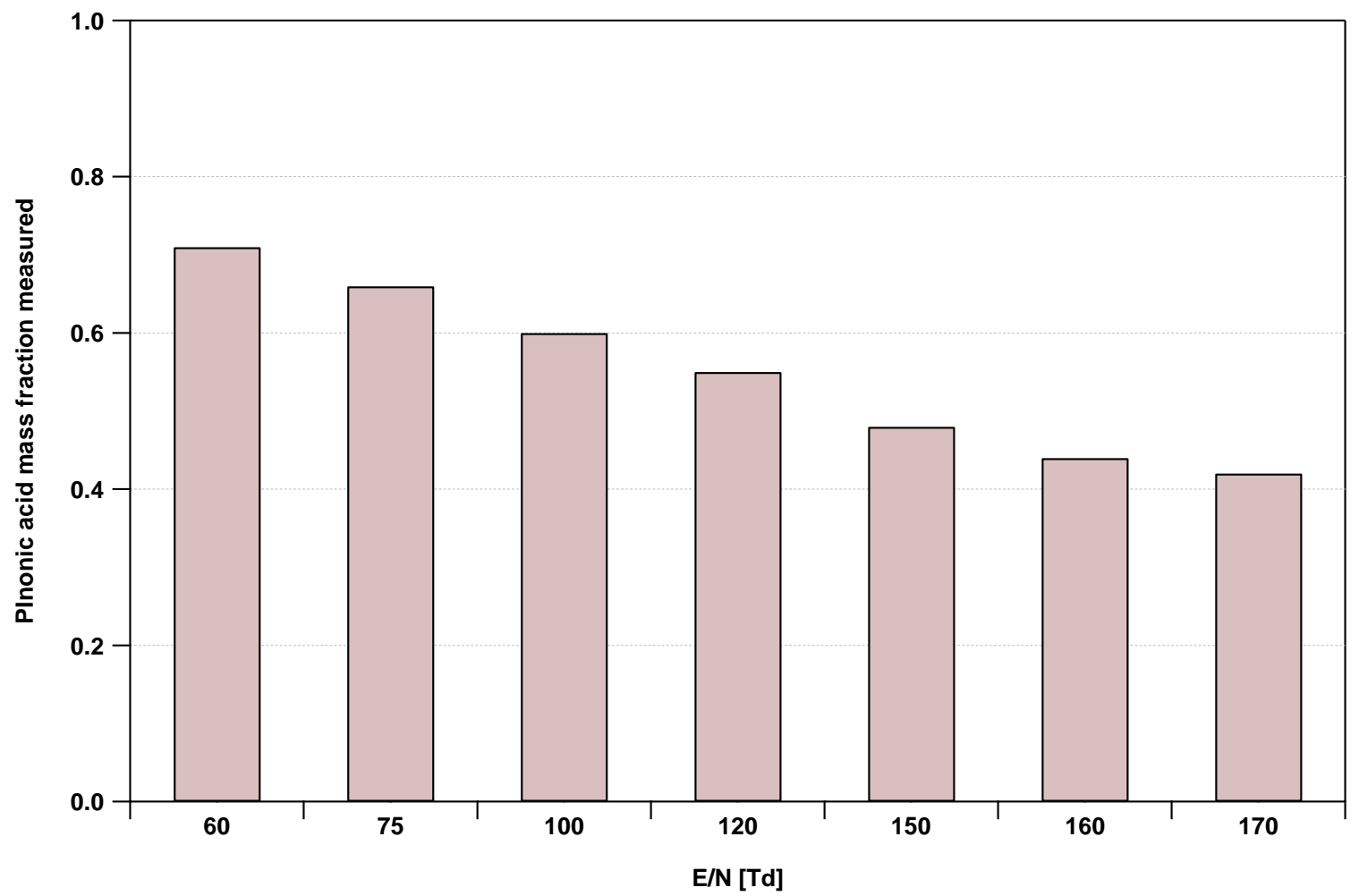

Figure S 10: Mass fraction of the pinonic acid particles compared to an SMPS, for the different E/N conditions of the CHARON-PTR-ToF-MS, ranging from 60 up to $173 \mathrm{Td}$. Assumption of uniform sensitivity is made and mass concentration is generated by taking the sum of all fragments and assuming all $\mathrm{m} / \mathrm{zs}$ represent parent molecules. 


\section{References}

Canagaratna, M. R., J. L. Jimenez, J. H. Kroll, Q. Chen, S. H. Kessler, P. Massoli, L. Hildebrandt Ruiz, E. Fortner, L. R. Williams, K. R. Wilson, J. D. Surratt, N. M. Donahue, J. T. Jayne, and D. R. Worsnop: Elemental ratio measurements of organic compounds using aerosol mass spectrometry: characterization, improved calibration, and implications, Atmospheric Chemistry and Physics, 15(1), 253-272, doi:10.5194/acp-15-253-2015, 2015.

Chen, J., and R. Griffin: Modeling secondary organic aerosol formation from oxidation of -pinene, -pinene, and limonene, Atmospheric Environment, 39(40), 7731-7744, doi:10.1016/j.atmosenv.2005.05.049, 2005.

Hohaus, T., I. Gensch, J. R. Kimmel, D. R. Worsnop, and A. Kiendler-Scharr: Experimental determination of the partitioning coefficient of $\beta$-pinene oxidation products in SOAs, Physical Chemistry Chemical Physics, 17(22), 14796-14804, doi:10.1039/C5CP01608H, 2015.

Jaoui, M., E. Corse, T. E. Kleindienst, J. H. Offenberg, M. Lewandowski, and E. O. Edney: Analysis of Secondary Organic Aerosol Compounds from the Photooxidation of d-Limonene in the Presence of NOX and their Detection in Ambient PM2.5, Environ Sci Technol, 40(12), 3819-3828, doi:10.1021/es052566z, 2006.

Jenkin, M. E.: Modelling the formation and composition of secondary organic aerosol from $\alpha$ - and $\beta$-pinene ozonolysis using MCM v3 Atmos. Chem. Phys., 4, 1741-1757, 2004.

Kundu, S., R. Fisseha, A. L. Putman, T. A. Rahn, and L. R. Mazzoleni: High molecular weight SOA formation during limonene ozonolysis: insights from ultrahigh-resolution FT-ICR mass spectrometry characterization, Atmospheric Chemistry and Physics, 12(12), 5523-5536, doi:10.5194/acp-12-5523-2012, 2012.

Leungsakul, S., M. Jaoui, and R. M. Kamens: Kinetic Mechanism for Predicting Secondary Organic Aerosol Formation from the Reaction of d-Limonene with Ozone, Environ Sci Technol, 39(24), 9583-9594, doi:10.1021/es0492687, 2005a.

Leungsakul, S., H. E. Jeffries, and R. M. Kamens: A kinetic mechanism for predicting secondary aerosol formation from the reactions of d-limonene in the presence of oxides of nitrogen and natural sunlight, Atmospheric Environment, 39(37), 7063-7082, doi:10.1016/j.atmosenv.2005.08.024, 2005 b.

Yu, J., D. R. Cocker, R. J. Griffin, R. C. Flagan, and J. H. Seinfeld: Gas-Phase Ozone Oxidation of Monoterpenes: Gaseous and Particulate Products, Journal of Atmospheric Chemistry, 34(2), 207-258, doi:10.1023/a:1006254930583, 1999. 